\title{
Synthesis, Cytotoxic Activity, and DNA Binding Properties of Copper (II) Complexes with Hesperetin, Naringenin, and Apigenin
}

\author{
Mingxiong Tan, ${ }^{1,2}$ Jinchan Zhu, ${ }^{1}$ Yingming Pan, ${ }^{1}$ Zhenfeng Chen, ${ }^{1}$ \\ Hong Liang, ${ }^{1}$ Huagang Liu, ${ }^{3}$ and Hengshan Wang ${ }^{1}$ \\ ${ }^{1}$ The Key Laboratory for the Chemistry and Molecular Engineering of Medicinal Resources, \\ School of Chemistry \& Chemical Engineering, Guangxi Normal University, Guilin 541004, China \\ ${ }^{2}$ Department of Chemistry and Biology, Yulin Normal College, Yulin 537000, China \\ ${ }^{3}$ Department of Pharmacology, Guangxi Medical University, Nanning 530021, China
}

Correspondence should be addressed to Hengshan Wang, wang_hengshan@yahoo.com.cn

Received 28 May 2009; Revised 28 July 2009; Accepted 4 August 2009

Recommended by Lorenzo Pellerito

Complexes of copper (II) with hesperetin, naringenin, and apigenin of general composition $\left[\mathrm{CuL}_{2}\left(\mathrm{H}_{2} \mathrm{O}\right)_{2}\right] \cdot \mathrm{nH} \mathrm{H}_{2} \mathrm{O}(\mathbf{1}-\mathbf{3})$ have been synthesized and characterized by elemental analysis, UV-Vis, FT-IR, ESI-MS, and TG-DTG thermal analysis. The free ligands and the metal complexes have been tested in vitro against human cancer cell lines hepatocellular carcinoma (HepG-2), gastric carcinomas (SGC-7901), and cervical carcinoma (HeLa). Complexes 1 and $\mathbf{3}$ were found to exhibit growth inhibition of SGC-7901 and HepG2 cell lines with respect to the free ligands; the inhibitory rate of complex $\mathbf{1}$ is $43.2 \%$ and $43.8 \%$, while complex 3 is $46 \%$ and 36\%, respectively. The interactions of complex 1 and its ligand Hsp with calf thymus DNA were investigated by UV-Vis, fluorescence, and CD spectra. Both complex 1 and Hsp were found to bind DNA in intercalation modes, and the binding affinity of complex 1 was stronger than that of free ligand.

Copyright (C) 2009 Mingxiong Tan et al. This is an open access article distributed under the Creative Commons Attribution License, which permits unrestricted use, distribution, and reproduction in any medium, provided the original work is properly cited.

\section{Introduction}

The success of cisplatin and its derivatives as anticancer agents has stimulated the development of metal-based compounds [1-4]. Recently, interests possessed in copper(II) complexes are increasing due to their possible medical uses as antitumor agents. And, new bioactive ligands, involving natural product ligands [5-7], have been applied for the design of $\mathrm{Cu}$-coordination novel drugs; for that, naturally occurring compounds have served as a major source of drugs for centuries [8-10].

Flavonoids are phenolic compounds widely distributed in plants, which display a variety of biological activities, such as antioxidant, anti-inflammatory, blood lipid-lowing, and anticarcinogenic activities [11-13]. Many flavonoids are natural chelators and, flavonoid metal complexes have showed significantly higher cytotoxic activity than those of the parent flavonoids, such as quercetin, morin, and chrysin and so forth [14-16]. Besides, it is demonstrated that the coordination of copper(II) ion with bioactive ligands can actually improve the pharmaceutical activity of the drugs themselves and reduce their toxicity effects [17-19].

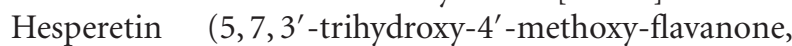
Hsp, Scheme 1), naringenin (4', 5, 7-trihydroxyflavanone, $\mathrm{Nrg}$, Scheme 1) and Apigenin (4', 5, 7-trihydroxyflavone, Apg, Scheme 1), are biologically active flavonoids, commonly found in fruits and vegetables [20]. They have been reported to exhibit antitumor effects against breast cancer and hepatoma HepG2 cell lines [21, 22]. In addition, some metal complexes of Hsp and Nrg have been found to exhibit antioxidant and anticancer activities $[23,24]$. Nrg schiff-base La(III) complex against the A-549 cell line was more potent than cisplatin at most experimental concentrations $[25,26]$. Also, $\mathrm{Cu}(\mathrm{II})$ complex of Nrg schiffbase possessed potent antioxidant activity and better than standard antioxidants like vitamin C and mannitol [27]. 
<smiles>COc1ccc([C@H]2CC(=O)c3c(O)cc(O)cc3O2)cc1O</smiles>

Hesperetin

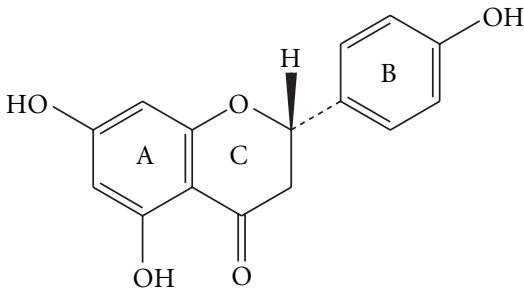

Naringenin

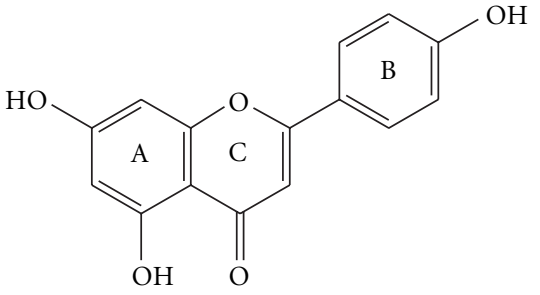

Apigenin

Scheme 1: Structures of the ligands.

The aim of this study is to prepare new copper(II)based antitumor compounds and investigate the synergistic effects upon flavonoids coordination with $\mathrm{Cu}$ (II) ion. In this paper, three copper(II) complexes with Hsp, Nrg, and Apg have been synthesized and characterized by elemental analysis, UV-Vis, FT-IR, ESI-MS, and TG-DTG thermal analysis, and their cytotoxic activities were estimated against HepG-2, SGC-7901, and HeLa cell lines in vitro. The binding properties with calf thymus DNA of Hsp and its $\mathrm{Cu}(\mathrm{II})$ complex, which have good activities against the tested cell lines, were investigated through UV-Vis, fluorescence, and circular dichroism (CD) spectroscopy.

\section{Experimental}

2.1. Instrumentation and Materials. Hesperetin, naringenin, and apigenin were purchased from Shaanxi Huike Botanical Development Co., Ltd., and the products (compounds purity $>98 \%$ ) were identified by spectral methods. The solvents and metallic salts used were analytical grade. All the materials were used as received without further purification unless noted specifically. Tris- $\mathrm{HCl}-\mathrm{NaCl}$ buffer solution $(5 \mathrm{mM}$ Tris, $50 \mathrm{mM} \mathrm{NaCl}$, pH was digital adjusted to 7.35 by titration with hydrochloric acid using a sartorius professional meter professional meter, tris(hydroxymethyl)aminomethane) (Tris) was prepared using double distilled water. Calf thymus DNA (ct-DNA) was purchased from Sino-American Biotech. Co. Ltd, Beijing. A Tris-buffer solution of ct-DNA gave a ratio of UV absorbance at $260 \mathrm{~nm}$ and $280 \mathrm{~nm}$ of $c a .1 .8 \sim 1.9: 1$, indicating that the DNA was sufficiently free of protein. The DNA concentration was determined spectrophotometrically from the molar absorption coefficient $\left(6600 \mathrm{M}^{-1} \mathrm{~cm}^{-1}\right)$ at $260 \mathrm{~nm}$. Stock solutions were stored at $4^{\circ} \mathrm{C}$ and used no more than 4 days after preparation. Infrared spectra were obtained on a Perkin-Elmer FTIR Spectrometer. Elemental analyse was carried out on a Perkin Elmer 2400 Series II CHNS/O elemental analyzer. TG-DTG thermal analyses of the complexes were investigated on a thermogravimetry differential thermal analysis apparatus (Pris Diamond, America). UVVis absorption was performed on a Varian Cary100 UV-Vis spectrophotometer. Fluorescence measurements were performed on a Shimadzu RF-530/PC spectrofluorophotometer.
The Circular Dichroic spectra of DNA were obtained by using a JASCO J-810 automatic recording spectropolarimeter operating at $25^{\circ} \mathrm{C}$. The region between 220 and $320 \mathrm{~nm}$ was scanned for each sample.

2.2. Synthesis of Complexes. Synthesis of $\left[\mathrm{Cu}(\mathrm{Hsp})_{2}\left(\mathrm{H}_{2} \mathrm{O}\right)_{2}\right]$. $\mathrm{H}_{2} \mathrm{O}$ (1): An ethanol solution (10 mL) of $\mathrm{Hsp}(0.0604 \mathrm{~g}$, $0.2 \mathrm{mmol}$ ) was added to a aqueous solution $(15 \mathrm{~mL})$ of $\mathrm{CuCl}_{2} \cdot 2 \mathrm{H}_{2} \mathrm{O}(0.0204 \mathrm{~g}, 0.12 \mathrm{mmol})$ and was adjusted $\mathrm{pH}$ to 7-8 with ammonia solution. The mixture was refluxed with stirring for 12 hours, and brown precipitate formed during reflux and then allowed to cool to room temperature and filtered. The solid was washed with water and ethanol, and then air-dried for 2 days. Calc. for $\left[\mathrm{Cu}(\mathrm{Hsp})_{2}\left(\mathrm{H}_{2} \mathrm{O}\right)_{2}\right] \cdot \mathrm{H}_{2} \mathrm{O}$, C, $53.37 ; \mathrm{H}, 4.48$. Found: C, $53.68 ; \mathrm{H}, 4.51 \%$. IR (KBr): 3423 , 1614, 1564, 1375, $1166 \mathrm{~cm}^{-1}$. ESI-MS: $\mathrm{m} / z 703$.

Synthesis of $\left[\mathrm{Cu}(\mathrm{Nrg})_{2}\left(\mathrm{H}_{2} \mathrm{O}\right)_{2}\right] \cdot \mathrm{H}_{2} \mathrm{O}$ (2): this green compound was synthesized by the same method as that employed for 1. Calc. for $\left[\mathrm{Cu}(\mathrm{Nrg})_{2}\left(\mathrm{H}_{2} \mathrm{O}\right)_{2}\right] \cdot \mathrm{H}_{2} \mathrm{O}, \mathrm{C}, 54.59$; $\mathrm{H}, 4.28$. Found: C, $54.75 ; \mathrm{H}, 4.26 \%$. IR (KBr): 3401,1613 , 1566, 1374, $1254 \mathrm{~cm}^{-1}$. ESI-MS: $m / z 642.4$.

Synthesis of $\left[\mathrm{Cu}(\mathrm{Apg})_{2}\left(\mathrm{H}_{2} \mathrm{O}\right)_{2}\right](3)$ : this yellow-green compound was synthesized by the same method as that employed for 1. Calc. for [ $\left.\mathrm{Cu}(\mathrm{Apg})_{2}\left(\mathrm{H}_{2} \mathrm{O}\right)_{2}\right], \mathrm{C}, 56.47 ; \mathrm{H}$, 3.48. Found: C, $56.81 ; \mathrm{H}, 3.76 \%$. IR (KBr): 3413, 1626, 1597, 1356, $1176 \mathrm{~cm}^{-1}$. ESI-MS: $m / z 638$.

2.3. Cytotoxic Activity Assay In Vitro. Cell lines: human cancer cell lines hepatocellular carcinoma (HepG-2), gastric carcinomas (SGC-7901), and cervical carcinoma (HeLa) were obtained from Shanghai Cell Bank in Chinese Academy of Sciences. Cell lines (Gibco, Scotland, UK) were grown in Dulbecco's modified Eagles medium (DMEN) at $37^{\circ} \mathrm{C}$ in a humidified atmosphere of $5 \% \mathrm{CO}_{2} / 95 \%$ air. Cytotoxicity evaluation: assays of cytotoxicity were conducted in 96-well, flat-bottomed microtitre plates. The supplemented culture medium with cell limes was added to the wells. Compounds were dissolved in the culture medium with $1 \%$ DMSO to various concentrations, and the solutions were subsequently added to a set of wells. Control wells contained supplemented media with $1 \%$ DMSO. The microtiter plates were incubated at $37^{\circ} \mathrm{C}$ in a humidified atmosphere of $5 \% \mathrm{CO}_{2} / 95 \%$ air for 
a further 3 days. Assessment of cytotoxicity was carried out by using a modified method of the Mosmann-based 3-(4, 5-dimethylthiazol-2-yl)-2, 5-diphenyltetrazolium bromide (MTT) assay. At the end of each incubation period, MTT solution $(10 \mu \mathrm{L}, 5 \mathrm{mg} / \mathrm{mL})$ was added into each well, and the cultures were incubated further for 4 hours at $37^{\circ} \mathrm{C}$ in a humidified atmosphere of 5\% CO2/95\% air. After removal of the supernatant, DMSO $(150 \mu \mathrm{L})$ was added to dissolve the formazan crystals. The absorbance was read by enzyme labelling instrument with $570 / 630 \mathrm{~nm}$ double wavelength measurement.

2.4. DNA Binding. The UV-Vis absorption titrations, fluorescence emission spectra, and $\mathrm{CD}$ absorption spectra studies were performed at room temperature. $\mathrm{Hsp}$ and its $\mathrm{Cu}(\mathrm{II})$ complex were all dissolved in a small amount of DMSO due to their poor solubility, then diluted to a concentration of $2.0 \times 10^{-5} \mathrm{~mol} / \mathrm{L}$ with Tris- $\mathrm{HCl}-\mathrm{NaCl}$ buffer solution $(5 \mathrm{mM}$ Tris, $50 \mathrm{mM} \mathrm{NaCl}, \mathrm{pH}=7.35)$. Absorption titrations were performed by using a fixed compound concentration $(2.0 \times$ $\left.10^{-5} \mathrm{~mol} / \mathrm{L}\right)$; ct-DNA stock solution $\left(1.0 \times 10^{-4} \mathrm{~mol} / \mathrm{L}\right)$ was added $30 \mu \mathrm{L}$ each time and gradually increased up to a sufficient concentration for studying. While measuring the absorption spectra, the solutions were allowed to incubate for 10 minutes before the absorption spectra were recorded, and an equal amount of ct-DNA was added to both the compound solution for the reference solution to eliminate the absorbance of ct-DNA itself. Fluorescence Emission spectra of compounds were performed by using a fixed compound concentration $\left(2.0 \times 10^{-5} \mathrm{~mol} / \mathrm{L}\right)$ and an increasing amount of DNA $\left(1.0 \times 10^{-4} \mathrm{~mol} / \mathrm{L}\right)$. Samples were observed between 200 and $800 \mathrm{~nm}$. The CD absorption spectra of ct-DNA $\left(1.0 \times 10^{-4} \mathrm{~mol} / \mathrm{L}\right)$ were recorded in the absence and presence of compounds $\left(2.0 \times 10^{-5} \mathrm{~mol} / \mathrm{L}\right)$. The sample solutions were mixed and allowed to equilibrate at room temperature for 60 minutes before measurements. Each sample solution was scanned in the range $200-400 \mathrm{~nm}$ UV-Vis region with a screening rate of $100 \mathrm{~nm} / \mathrm{min}$ at room temperature.

\section{Results and Discussion}

3.1. Synthesis of the Complexes. The $\mathrm{Cu}(\mathrm{II})$ complexes were synthesized by aqueous solution of $\mathrm{CuCl} 2 \cdot 2 \mathrm{H} 2 \mathrm{O}$ and the ethanol aqueous solution of Hsp, $\mathrm{Nrg}$ or Apg in $1: 2$ molar ratio (metal salt/ligands). Ligands were deprotonated by adding ammonia solution. The structures of copper(II) complexes were characterized by elemental analysis, UV-Vis, FT-IR, UV-Vis, TG-DTG, and ESI-MS measurements.

The elemental analysis data of the copper(II) complexes agreed with the theoretical values within the limit of experimental error. The ESI-MS of complexes were investigated in $\mathrm{H}_{2} \mathrm{O}$-DMSO $(1: 1)$ solution, the characteristic peaks at $\mathrm{m} / \mathrm{z}$ 703 and 642 corresponding to $\left[\mathrm{M}+\mathrm{H}-\mathrm{H}_{2} \mathrm{O}\right]^{+}$of complexes 1 and 2 , and that of peak at $\mathrm{m} / z 638$ assigning to $[\mathrm{M}+\mathrm{H}]^{+}$of complex 3.

UV-Vis spectrum of free ligands and their $\mathrm{Cu}$ complexes suggested that 4-keto and 5-hydroxy region of the flavonoids may be considered as the possible chelating sites. For
TABle 1: FT-IR spectrum data $\left(\mathrm{cm}^{-1}\right)$ for the free ligands Apg, Hsp, $\mathrm{Nrg}$, and their $\mathrm{Cu}(\mathrm{II})$ complexes

\begin{tabular}{lccccc}
\hline Compound & $\nu(\mathrm{C}=\mathrm{O})$ & $\nu(\mathrm{C}=\mathrm{C})$ & $\nu(\mathrm{C}-\mathrm{OH})$ & $\nu(\mathrm{O}-\mathrm{H})$ & $\nu(\mathrm{M}-\mathrm{O})$ \\
\hline Apg & 1651 & 1608 & 1354 & 3291 & - \\
Apg-Cu & 1626 & 1597 & 1356 & 3413 & 607 \\
Hsp & 1636 & 1612 & 1360 & 3132 & - \\
$\mathrm{Hsp}-\mathrm{Cu}$ & 1614 & 1564 & 1375 & 3423 & 598 \\
Nrg & 1629 & 1603 & 1388 & 3290 & - \\
Nrg-Cu & 1613 & 1566 & 1374 & 3401 & 595 \\
\hline
\end{tabular}

TABLE 2: Thermal analytical data for complexes.

\begin{tabular}{lcccccc}
\hline Compound & \multicolumn{3}{c}{$\begin{array}{c}\text { Dehydration } \\
\text { temperature }\left({ }^{\circ} \mathrm{C}\right)\end{array}$} & \multicolumn{3}{c}{$\begin{array}{c}\text { Decomposition } \\
\text { temperature }\left({ }^{\circ} \mathrm{C}\right)\end{array}$} \\
\hline & $\mathrm{T} 1$ & $\mathrm{~T} 2$ & $\begin{array}{c}\text { Weight } \\
\text { loss }(\%)\end{array}$ & T3 & T4 & $\begin{array}{c}\text { Total } \\
\text { weight loss } \\
(\%)\end{array}$ \\
\hline $\mathrm{Hsp}-\mathrm{Cu}$ & 100 & 250 & 7.2 & 347 & 540 & 55.9 \\
Nrg-Cu & 94 & 117 & 7.9 & 248 & 440 & 76.5 \\
Apg-Cu & - & 247 & 5.2 & 420 & 580 & 55.9 \\
\hline
\end{tabular}

T1-T2: temperature range corresponding to complex dehydration; T3-T4: temperature range corresponding to complex decomposition.

example, free Apg exhibits an UV-Vis absorption maximum in DMSO solution at $206-250 \mathrm{~nm}$, corresponding to the A ring portion, and a week band at $268-316 \mathrm{~nm}$, corresponding to the $\mathrm{B}$ ring portion. Upon binding with the $\mathrm{Cu}(\mathrm{II})$ ion, forming complex 3 , the maximum absorption band is shifted to $235-286 \mathrm{~nm}$ and the weak band shifted to $290-340 \mathrm{~nm}$ with respect to the free flavonoid, suggesting an interaction of the $\mathrm{Cu}(\mathrm{II})$ ion with the condensed ring of the flavanone in positions 4 and 5 . These results are in agreement with the results of others, [28-31] which indicate that this band shift is caused by the binding of the metal ion in this position.

FT-IR spectrum data in $\mathrm{KBr}$ of free ligands and their $\mathrm{Cu}$ complexes were compared in Table 1. The absorption around $3200 \mathrm{~cm}^{-1}$ due to phenolic hydroxyl in the free ligands shows significantly spectral change in all the $\mathrm{Cu}$ complexes, indicating the chelate formation through hydroxyl group. The $\mathrm{Cu}$ complexes show a medium broad band around $3400 \mathrm{~cm}^{-1}$ indicating coordinated water, later confirmed by TG-DTG thermal analysis. The intense absorption bands due to $v(\mathrm{C}=\mathrm{O})$ of free ligands at $1630-1650 \mathrm{~cm}^{-1}$ has also shifted to lower frequencies at $1623-1626 \mathrm{~cm}^{-1}$ in the $\mathrm{Cu}$ complexes. Thus it suggests that flavonoids are coordinated with $\mathrm{Cu}$ (II) through oxygen atoms of $-\mathrm{OH}$ and $\mathrm{C}=\mathrm{O}$ groups [31]. This contention is further confirmed by the presence of $\nu(\mathrm{M}-\mathrm{O})$ bands at about $600 \mathrm{~cm}^{-1}$ in the far IR frequency region.

The TG-DTG curves and thermal data for the dehydration and decomposition of the complexes are given in Table 1 and Figure 1. The results showed that the thermal decomposition of complex $\mathbf{1}$ displayed three stages from $30^{\circ} \mathrm{C}$ to $600^{\circ} \mathrm{C}$. The first stage of decomposition from $30^{\circ} \mathrm{C}$ to $100^{\circ} \mathrm{C}$ was connected with the dehydration processes. The mass loss value of $2.09 \%$ was involved in the loss for two water molecules in the outer coordination sphere, which 


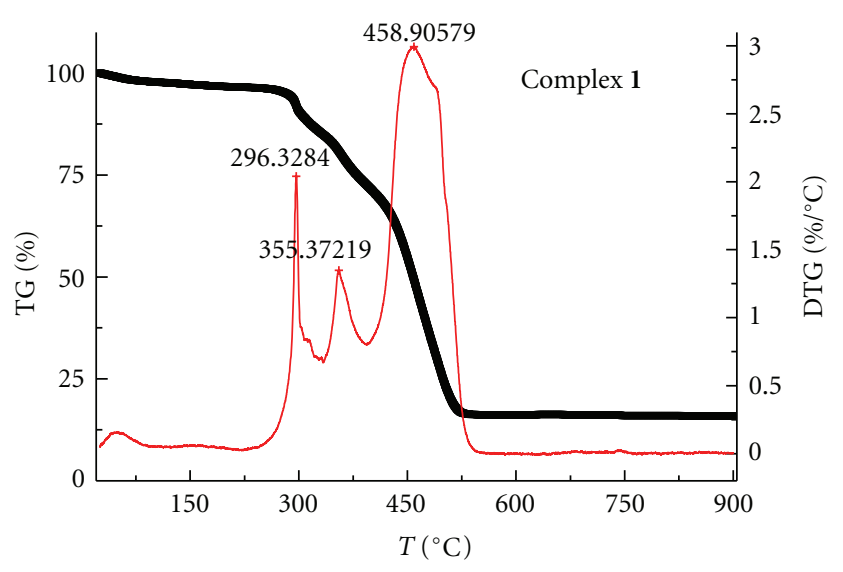

(a)

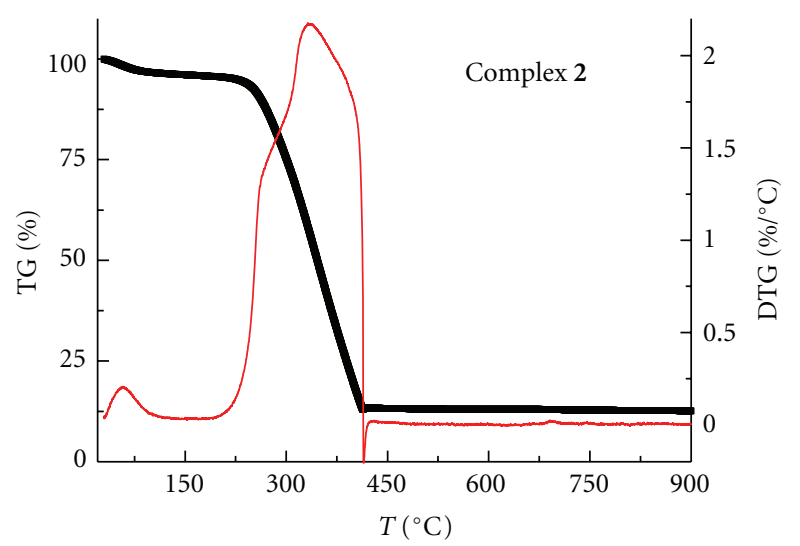

(b)

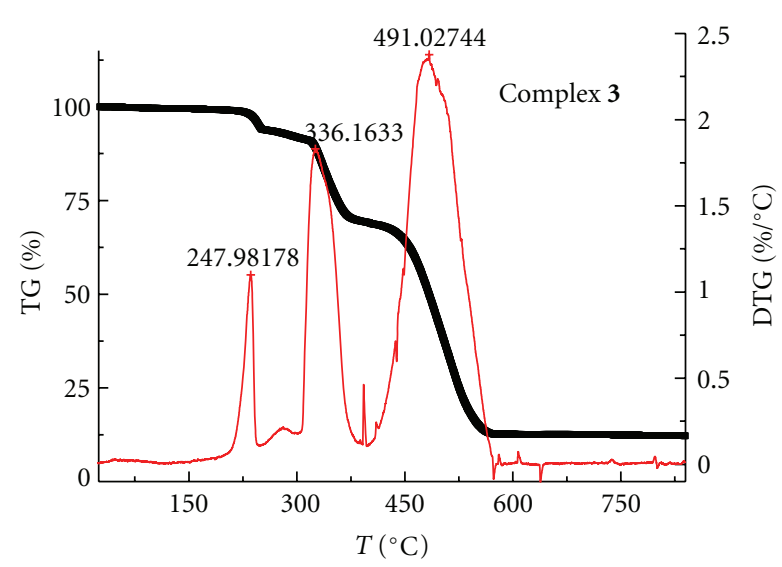

(c)

Figure 1: TG-DTG curves of the Cu(II) complexes.

was in close agreement with the calculated mass loss value of $2.6 \%$. The next dehydration processes appeared in the temperature ranges from $250^{\circ} \mathrm{C}$ to $300^{\circ} \mathrm{C}$. In fact, it was very difficult to distinguish between the dehydration steps for inner and outer spheres from the graphic data. However, the total observed mass loss value of $5.2 \%$ was in close agreement with the calculated mass loss value of $5.13 \%$ for the two coordinated water molecules. The last mass loss stages were considered as the case of the decomposition of the ring breaking of the ligand and the formation of metal oxide. Complex 2 exhibits a sharp weight loss at temperature of about $253^{\circ} \mathrm{C}-440^{\circ} \mathrm{C}$, which corresponds to the degradation of the ligand molecules and the formation of metal oxides. The dehydration process occurs at temperature range of $30^{\circ} \mathrm{C}-94^{\circ} \mathrm{C}$ and $124^{\circ} \mathrm{C}-253^{\circ} \mathrm{C}$, corresponding to the outer sphere and coordinated water molecules. The thermal decomposition process of complex $\mathbf{3}$ is basically the same as that of complex 1 . The dehydration process occurs in only one mass-loss step up to $247^{\circ} \mathrm{C}$ with $5.2 \%$, which is in close agreement with the calculated mass loss value of $5.5 \%$ for the two coordinated water molecules in inner spheres.

Based on these results, the possible structures of the complexes were suggested. As shown in Scheme 2, the copper(II) complexes have the general formula $\left[\mathrm{Cu}(\mathrm{L})_{2}\left(\mathrm{H}_{2} \mathrm{O}\right)_{2}\right] \cdot \mathrm{nH}_{2} \mathrm{O}$, where $\mathrm{L}$ is the ligands, and $n=0$ for Apg, and $\mathrm{n}=1$ for Hsp or Nrg. The complexes are air stable for extended periods and soluble in DMF, dimethyl sulphoxide (DMSO), slightly soluble in $\mathrm{Me}_{2} \mathrm{CO}$, and $\mathrm{CH}_{3} \mathrm{OH}$, but scarcely soluble in water.

3.2. Cytotoxic Activity Assay In Vitro. Cytotoxicities in vitro of Hsp, Nrg, and Apg and their copper(II) complexes have been estimated by MTT assay [32] against three typical human tumour cell lines involving HepG-2, SGC-7901 and HeLa. As shown in Figure 2, it is remarkable that complexes $\mathbf{1}$ and $\mathbf{3}$ exhibited cytotoxicity higher than that of complex $\mathbf{2}$ against the selected cell lines. Against the SGC-7901 tumour cell line, the activity of complex $\mathbf{1}$ is $43.2 \%$, while $\mathbf{3}$ is $46 \%$, fifteen times stronger than that of Apg, and against HepG2, the activity of complex $\mathbf{1}$ is $43.8 \%$, while complex 3 is $36 \%$, ten times stronger than that of Apg. However, complex 2 showed relatively significant inhibitory rate only against HepG2 cell line than that of Nrg.

$\mathrm{Nrg}$ and Apg are structurally similar with the same A and $\mathrm{B}$ rings, and Apg is a planar molecule in its rings $\mathrm{A}$ and C. The ligand Apg was found to show lower activities against the tested cell lines than the analogous ligand $\mathrm{Nrg}$. However, the $\mathrm{Cu}$ (II) complex of Apg exhibited higher activity than the $\mathrm{Cu}(\mathrm{II})$ complex of $\mathrm{Nrg}$, presumably the flavone planar structure of Apg is important for retaining its original planarity in the $\mathrm{Cu}(\mathrm{II})$ complex and plays an important role in the enhanced antitumour activity of the complex [33]. It is noteworthy that, $\mathrm{Hsp}$ and $\mathrm{Nrg}$ share similar structures but have different hydroxyl $(\mathrm{OH})$ substitutions in ring $\mathrm{B}$. In contrast to the inhibitory activity of the $\mathrm{Cu}$ (II) complexes of $\mathrm{Nrg}$ and Hsp, the high activity of $\mathrm{Cu}(\mathrm{II})$ complex with Hsp may be related to the different hydroxyl $(\mathrm{OH})$ substitutions in ring $\mathrm{C}$ and the synergistic action of copper(II) ion with ligands [34-36].

3.3. DNA Binding Studies of 1 and Hsp. DNA is the primary pharmacological target of many antitumor compounds. Conformational changes of DNA directly affect genetic expression, which is closely related to carcinogenesis and anticarcinogenesis. Similarly, interactions between small molecules and DNA rank among the primary action mechanisms of antitumour activity. DNA replication in tumour cells will be blocked by the intercalation of small 


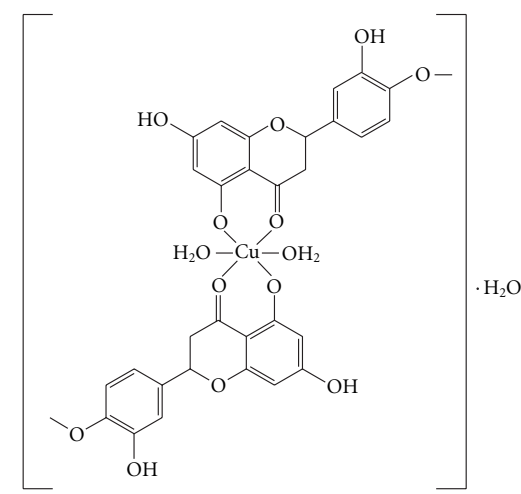

Complex 1

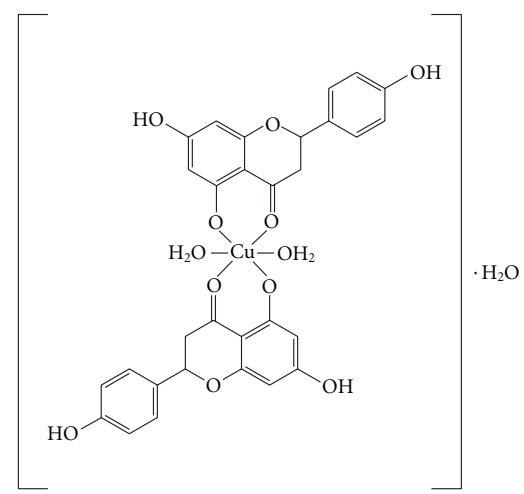

Complex 2

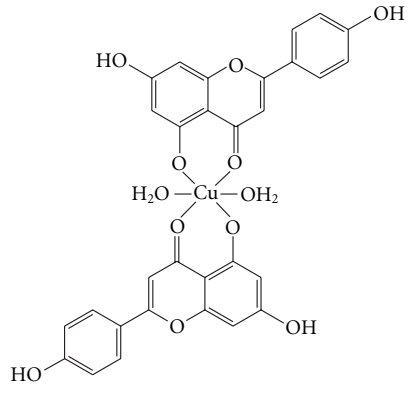

Complex 3

Scheme 2: The possible structures of the $\mathrm{Cu}(\mathrm{II})$ complexes.

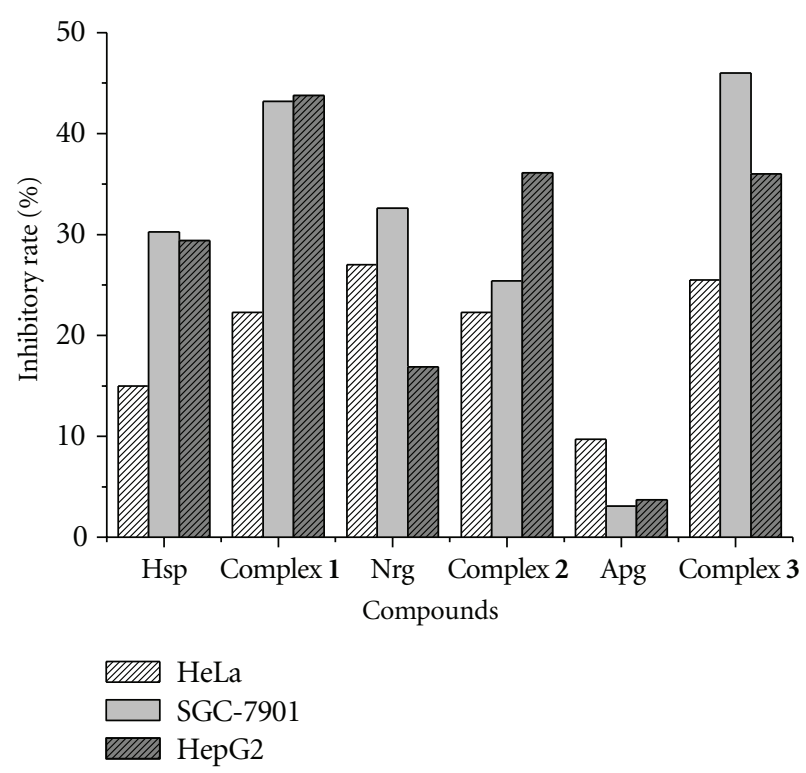

FIgURE 2: Inhibitory rate of complexes against the tested cell lines.

molecule between the base pairs of DNA [37, 38]. Generally, active compounds are required to possess approximately planar structure, with a medium-sized planar area and some hydrophobic character. In order to investigate the binding properties with DNA of Hsp and its copper(II) complexes, which have significant effect against the tested cell lines, a series of spectroscopic studies including UV-Vis, fluorescence, and CD spectra were carried out.

It is well documented that complexes copper(II) are capable of interaction with nucleic acids [39-41], and intercalative $\pi \pm \pi$ stacking of the aromatic rings of the metal complexes with the DNA bases affects the transition dipoles of the molecules and usually leads to a reduction in its absorbance [42]. The absorption titrations were carried out to determine the DNA binding of Hsp and its copper(II) complex in tris(hydroxymethyl)aminomethane (Tris) buffer.
The UV-Vis absorption spectra of Hsp and complex $\mathbf{1}$ in the absence and presence of calf thymus DNA are shown in Figure 3. The results indicated that the absorption spectrum of Hsp was similar to that of complex $\mathbf{1}$ with an intense absorption band around $322 \mathrm{~nm}$. After the addition of ctDNA, the absorption bands of Hsp and complex 1 at 322 $\mathrm{nm}$ both exhibited obvious hypochromism about $30.3 \%$ for Hsp, $39.4 \%$ for complex 1, although there was no obvious red shift.

In order to investigate the interaction pattern of Hsp and complex 1 with ct-DNA, fluorescence emission titration analyses were undertaken. The fluorescence emission spectra of Hsp and complex 1 in the absence and presence of calf thymus DNA are shown in Figure 4. Hsp showed a weak emission band around $284 \mathrm{~nm}$, and complex 1 exhibited a strong emission band around $361 \mathrm{~nm}$. With the addition of ct-DNA, the emission intensity of Hsp caused decrease, whereas that of complex $\mathbf{1}$ displayed enhancement. The emission intensity decrease of Hsp in the presence of DNA may be caused by the fact that Hsp being a small hydrophobic molecule can be adsorbed by hydrophobic group on the surface of DNA. Such a characteristic change is often observed in DNA interactions [14]. The emission intensity increase of complex $\mathbf{1}$ on addition of ct-DNA is ascribed to a decrease of the collisional frequency of the solvent molecules with the complex which caused by the planar aromatic group of the complex stacks between adjacent base pairs of ct-DNA [43]. Moreover, the emission intensity of Hsp decreased significantly reaching saturation with an decreasing ratio of 7.26 at the $[\mathrm{DNA}] /[\mathrm{Hsp}]$ ratio of $8: 1$, whereas that of complex 1 enhanced reaching saturation with an incremental ratio of 1.94 at the [DNA]/[Hsp] ratio of $5: 1$. These variations may be caused by the fact that the interaction degree was related to the planar area and hydrophobic character, suggesting the binding affinity of complex $\mathbf{1}$ is stronger than that of free ligand.

Circular dichroism (CD) is a useful technique to assess whether nucleic acids undergo conformational changes as a result of complex formation or changes in the environment [44]. The DNA helix has a right-hand chiral structure, 


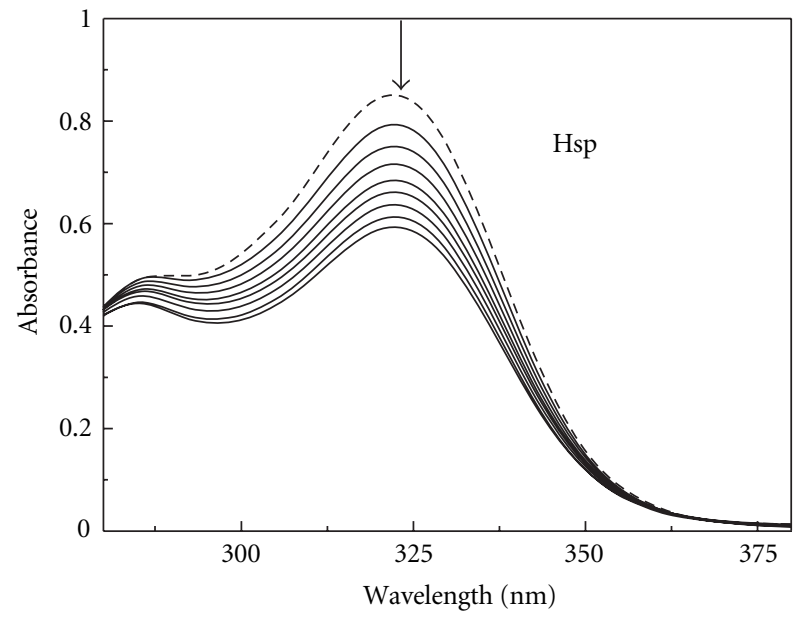

(a)

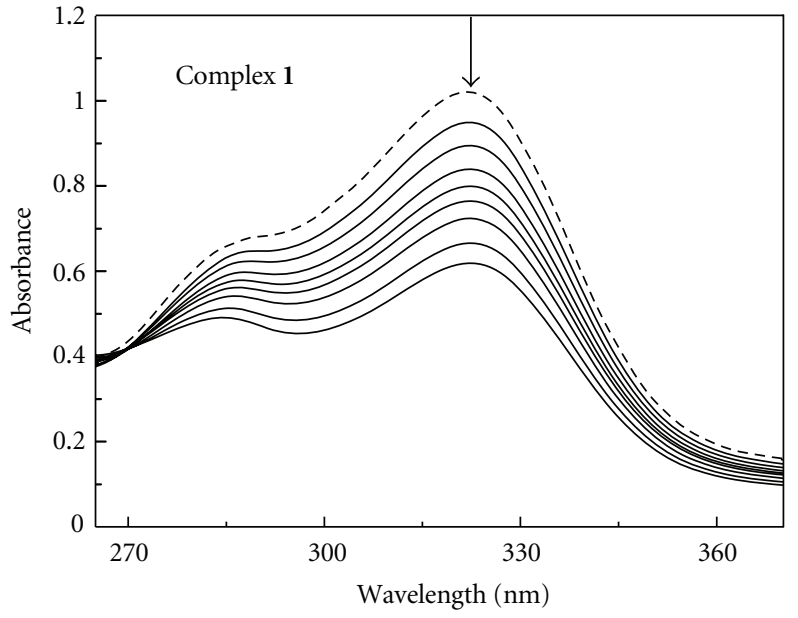

(b)

Figure 3: UV-Vis spectra of Hsp and complex 1 in the absence (- - -) and presence (-) of increasing amounts DNA.

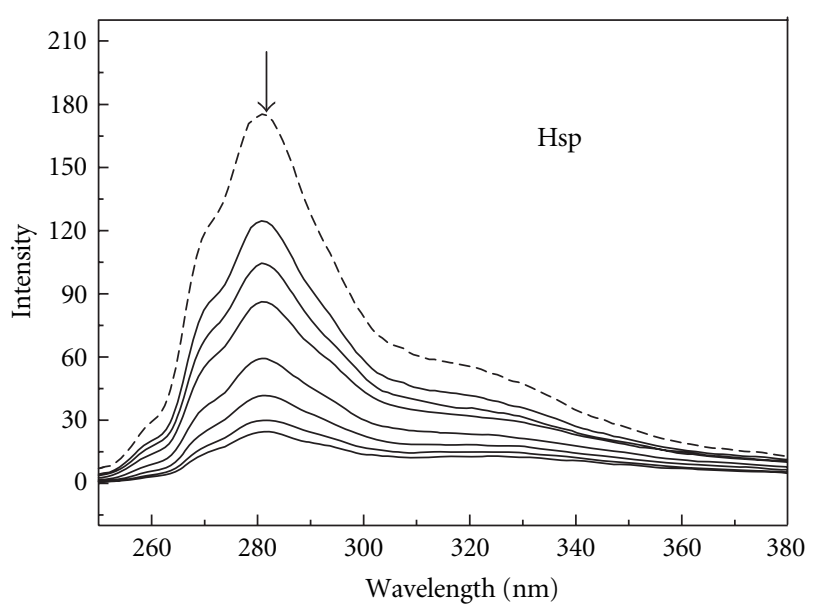

(a)

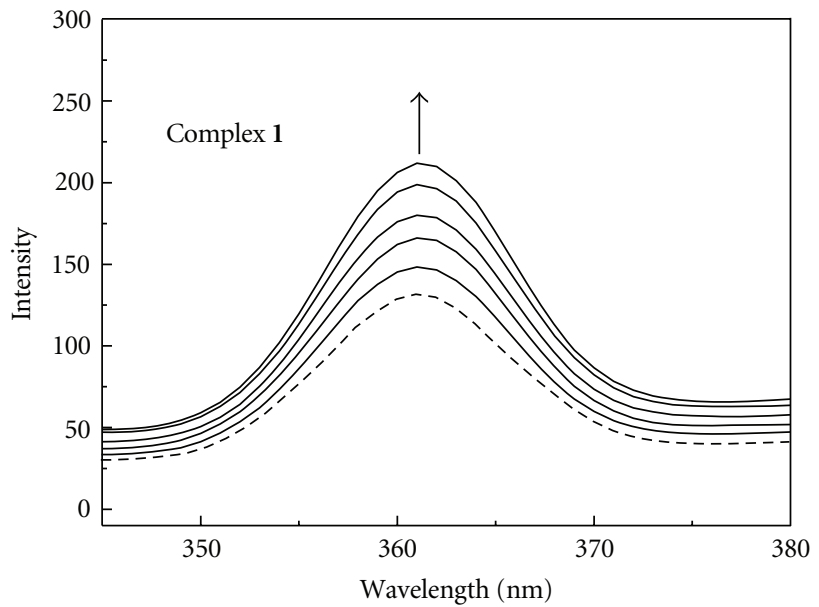

(b)

FIgURE 4: Emission spectra of Hsp and 1 in the absence (-- - ) and presence (-) of increasing amounts of DNA.

maintaining the $\mathrm{B}$ conformation in solution. The $\mathrm{CD}$ absorption spectrum is very sensitive to conformational changes in DNA; generally, in noncovalent binding states, electrostatic and groove bindings show no significant $C D$ spectral perturbation, because these two binding modes do not influence the secondary structure of DNA. The observed intensity change can be attributed to an intercalation mode when small planar molecules interact with DNA.

As shown in Figure 5, the CD spectra of ct-DNA show a positive band at $275 \mathrm{~nm}$ and a negative band at $245 \mathrm{~nm}$, due to base stacking and right-hand helicity, respectively, consistent with the characteristic B conformation of DNA $[45,46]$. With addition of the compounds, the intensities of the negative and positive bands decrease, but no red shift is observed. These alterations in the CD spectrum of
DNA indicate strong conformational changes by Hsp and complex 1. Also, Hsp and complex 1 bind DNA mainly by intercalation mode.

Based on the UV-Vis spectral, fluorescence and CD measurements revealed that, with the addition of increasing ct-DNA, complexes exhibited obviously hypochromism, fluorescence emission intensity enhancement, and CD spectrum change, which are important evidences of complex interacting with the DNA by intercalation. In summary, Hsp and complex 1 bind DNA mainly by intercalation mode, and the binding affinity of complex $\mathbf{1}$ is stronger than that of free ligand.

In addition, interactions of complexes 2 and 3 and their ligands with calf thymus DNA were also investigated under the same experiment condition. Similar results were 


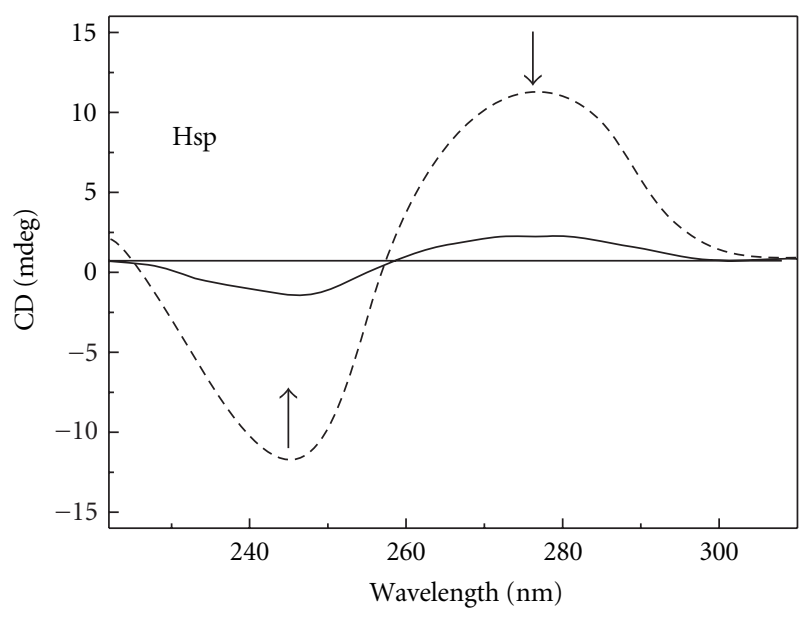

(a)

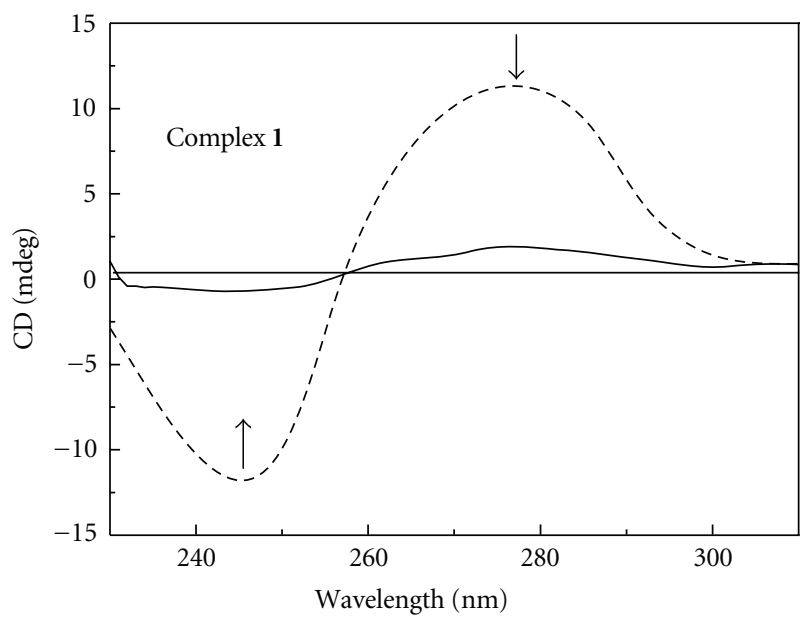

(b)

FIgURE 5: CD spectra of ct-DNA of Hsp and 1 in the absence (- - - -) and presence $(-)$ of complexes.

obtained, and no obvious differences in the DNA binding mode were founded.

\section{Conclusion}

Three flavonoids copper(II) complexes were synthesized, and their cytotoxic activities were estimated against HepG2, SGC-7901 and HeLa cell lines in vitro. The results showed that complexes $\mathbf{1}$ and $\mathbf{3}$ showed higher inhibitory rate than their free ligands against SGC-7901 and HepG2 cell lines; the inhibitory rate of complex 1 was $43.2 \%$ and $43.8 \%$, while complex 3 was $46 \%$ and $36 \%$, respectively. In comparison with complex 2, complexes 1 and 3 exhibited higher cytotoxicity towards selected cell lines, and complex 2 showed relatively significant inhibitory rate only against HepG2 cell lines than that of Nrg. The difference in inhibition rates between the $\mathrm{Cu}$ (II) complexes of Apg and Nrg was presumably due to the flavone planar structure of Apg. In contrast to the inhibitory activity of the $\mathrm{Cu}$ (II) complexes with $\mathrm{Nrg}$ and Hsp, the high activity of $\mathrm{Cu}(\mathrm{II})$ complex with Hsp may be related to the different hydroxyl $(\mathrm{OH})$ substitutions in ring $\mathrm{B}$. The binding properties with calf thymus DNA revealed that $\mathrm{Hsp}$ and its $\mathrm{Cu}$ (II) complex bind DNA mainly by intercalation mode. It confirmed that DNA is an important target in cellular systems for these metal-based compounds derived from flavonoids. The most important contribution of this research is that the synergistic enhancement effects of flavonoids with copper(II) ion may be benefit to further development as promising potential metal-based anticancer drug.

\section{Acknowledgments}

This study was supported by 973 project (2007CB516805), Key Technology R\&D program (no. 2006BAI06A18-14), the Natural Science Foundation of Guangxi Province (no. 05112001-3B2, 0832096, and 0832024), and the Project of the Key Laboratory of Medicinal Chemical Resources and Molecular Engineering, Guangxi Normal University, China (0630006-5D09), as well as Guangxi's Medicine Talented Persons Small Highland Foundation (0808).

\section{References}

[1] K. Tanaka, A. Tengeiji, T. Kato, N. Toyama, M. Shiro, and M. Shionoya, "Efficient incorporation of a copper hydroxypyridone base pair in DNA," Journal of the American Chemical Society, vol. 124, no. 42, pp. 12494-12498, 2002.

[2] A. P. Kozikowski, W. Tuckmantel, and G. Powis, "Synthesis and biological activity of D-3-deoxy-3-fluorophosphatidylinositol. A new direction in the design of non-DNA targeted anticancer agents," Angewandte Chemie, vol. 31, no. 10, pp. 1379-1381, 1992.

[3] L.-J. Ming, "Structure and function of "metalloantibiotics"," Medicinal Research Reviews, vol. 23, no. 6, pp. 697-762, 2003.

[4] D.-L. Ma and C.-M. Che, "A bifunctional platinum(II) complex capable of intercalation and hydrogen-bonding interactions with DNA: binding studies and cytotoxicity," Chemistry, vol. 9, no. 24, pp. 6133-6144, 2003.

[5] K. Toshima, H. Ouchi, Y. Okazaki, et al., "Artificial anthraquinone-carbohydrate hybrids: design, synthesis, DNA binding, and cytotoxicity," Angewandte Chemie, vol. 36, no. 24, pp. 2748-2752, 1997.

[6] W. Dürckheimer, "Tetracyclines: chemistry, biochemistry, and structure-activity relations," Angewandte Chemie, vol. 14, no. 11, pp. 721-734, 1975.

[7] R. F. Anderson, S. S. Shinde, M. P. Hay, and W. A. Denny, "Potentiation of the cytotoxicity of the anticancer agent tirapazamine by benzotriazine N-oxides: the role of redox equilibria," Journal of the American Chemical Society, vol. 128, no. 1, pp. 245-249, 2006.

[8] P. M. Takahara, C. Frederick, and S. J. Lippard, "Crystal structure of the anticancer drug cisplatin bound to duplex DNA," Journal of the American Chemical Society, vol. 118, no. 49, pp. 12309-12321, 1996.

[9] D. Steinborn, H. Junicke, and C. Bruhn, "Carbohydrates coordinated to platinum(IV) through hydroxyl groups: a new class of platinum complexes with bioactive ligands," Angewandte Chemie International Edition, vol. 36, no. 23, pp. 2686-2688, 1997. 
[10] I. Kostova, G. Momekov, T. Tzanova, and M. Karaivanova, "Synthesis, characterization, and cytotoxic activity of new lanthanum(III) complexes of bis-coumarins," Bioinorganic Chemistry and Applications, vol. 2006, p. 25651, 2006.

[11] A. Garg, S. Garg, L. J. D. Zaneveld, and A. K. Singla, "Chemistry and pharmacology of the Citrus bioflavonoid hesperidin," Phytotherapy Research, vol. 15, no. 8, pp. 655-669, 2001.

[12] D. Susanti, H. M. Sirat, F. Ahmad, R. M. Ali, N. Aimi, and M. Kitajima, "Antioxidant and cytotoxic flavonoids from the flowers of Melastoma malabathricum L," Food Chemistry, vol. 103, no. 3, pp. 710-716, 2007.

[13] S. Kanno, A. Tomizawa, T. Ohtake, K. Koiwai, M. Ujibe, and M. Ishikawa, "Naringenin-induced apoptosis via activation of NF- $\kappa \mathrm{B}$ and necrosis involving the loss of ATP in human promyeloleukemia HL-60 cells," Toxicology Letters, vol. 166, no. 2, pp. 131-139, 2006.

[14] Y. M. Song, J. W. Kang, Z. H. Wang, X. Q. Lua, J. Z. Gao, and L. F. Wang, "Study on the interactions between CuL and Morin with DNA," Journal of Inorganic Biochemistry, vol. 91, no. 3, pp. 470-474, 2002.

[15] Y.-B. Zeng, N. Yang, W.-S. Liu, and N. Tang, "Synthesis, characterization and DNA-binding properties of $\mathrm{La}$ (III) complex of chrysin," Journal of Inorganic Biochemistry, vol. 97, no. 3, pp. 258-264, 2003.

[16] J. Zhou, L.-F. Wang, J.-Y. Wang, and N. Tang, "Synthesis, characterization, antioxidative and antitumor activities of solid quercetin rare earth(III) complexes," Journal of Inorganic Biochemistry, vol. 83, no. 1, pp. 41-48, 2001.

[17] S. Zhang, C. Tu, X. Wang, et al., "Novel cytotoxic copper(II) complexes of 8-aminoquinoline derivatives: crystal structure and different reactivity towards glutathione," European Journal of Inorganic Chemistry, vol. 2004, no. 20, pp. 4028-4035, 2004.

[18] M. Baldini, M. B. Ferrari, F. Bisceglie, G. Pelosi, S. Pinelli, and P. Tarasconi, " $\mathrm{Cu}(\mathrm{II})$ complexes with heterocyclic substituted thiosemicarbazones: the case of 5-formyluracil. Synthesis, characterization, X-ray structures, DNA interaction studies, and biological activity," Inorganic Chemistry, vol. 42, no. 6, pp. 2049-2055, 2003.

[19] X. Sheng, X. M. Lu, Y. T. Chen, et al., "Synthesis, DNAbinding, cleavage, and cytotoxic activity of new 1,7-Dioxa4,10-diazacyclododecane artificial receptors containing bisguanidinoethyl or diaminoethyl doubl side arms," Chemistry, vol. 13, no. 34, pp. 9703-9712, 2007.

[20] E. Tripoli, M. L. Guardia, S. Giammanco, D. D. Majo, and M. Giammanco, "Citrus flavonoids: molecular structure, biological activity and nutritional properties: a review," Food Chemistry, vol. 104, no. 2, pp. 466-479, 2007.

[21] L. G. Korkina and I. B. Afanaśev, "Antioxidant and chelating properties of flavonoids," Advances in pharmacology, vol. 38, pp. 151-163, 1997.

[22] R. M. S. Pereira, N. E. D. Andrades, N. Paulino, et al., "Synthesis and characterization of a metal complex containing naringin and $\mathrm{Cu}$, and its antioxidant, antimicrobial, antiinflammatory and tumor cell cytotoxicity," Molecules, vol. 12, no. 7, pp. 1352-1366, 2007.

[23] F. V. So, N. Guthrie, A. F. Chambers, M. Moussa, and K. K. Carroll, "Inhibition of human breast cancer cell proliferation and delay of mammary tumorigenesis by flavonoids and citrus juices," Nutrition and Cancer, vol. 26, no. 2, pp. 167-181, 1996.

[24] L.-C. Chiang, L. T. Ng, I.-C. Lin, P.-L. Kuo, and C.-C. Lin, "Anti-proliferative effect of apigenin and its apoptotic induction in human HepG2 cells," Cancer Letters, vol. 237, no. 2, pp. 207-214, 2006.
[25] B.-D. Wang, Z.-Y. Yang, Q. Wang, T.-K. Cai, and P. Crewdson, "Synthesis, characterization, cytotoxic activities, and DNAbinding properties of the $\mathrm{La}(\mathrm{III})$ complex with naringenin schiff-base," Bioorganic \& Medicinal Chemistry, vol. 14, no. 6, pp. 1880-1888, 2006.

[26] T.-R. Li, Z.-Y. Yang, B.-D. Wang, and D.-D. Qin, "Synthesis, characterization, antioxidant activity and DNA-binding studies of two rare earth(III) complexes with naringenin2-hydroxy benzoyl hydrazone ligand," European Journal of Medicinal Chemistry, vol. 43, no. 8, pp. 1688-1695, 2008.

[27] T.-R. Li, Z.-Y. Yang, and B.-D. Wang, "Synthesis, characterization and antioxidant activity of naringenin Schiff base and its $\mathrm{Cu}(\mathrm{II}), \mathrm{Ni}(\mathrm{II}), \mathrm{Zn}(\mathrm{II})$ complexes," Chemical and Pharmaceutical Bulletin, vol. 55, no. 1, pp. 26-28, 2007.

[28] G. M. Escandar and L. F. Sala, "Complexing behavior of rutin and quercetin," Canadian Journal of Chemistry, vol. 69, no. 1212, pp. 1994-2001, 1991.

[29] P. Viswanathan, V. Sriram, and G. Yogeeswaran, "Sensitive spectrophotometric assay for 3-hydroxy-substituted flavonoids, based on their binding with molybdenum, antimony, or bismuth," Journal of Agricultural and Food Chemistry, vol. 48, no. 7, pp. 2802-2806, 2000.

[30] E. Woźnicka, M. Kopacz, M. Umbreit, and J. Kłos, "New complexes of $\mathrm{La}(\mathrm{III}), \mathrm{Ce}(\mathrm{III}), \mathrm{Pr}(\mathrm{III}), \mathrm{Nd}(\mathrm{III}), \mathrm{Sm}$ (III), Eu(III) and Gd(III) ions with morin," Journal of Inorganic Biochemistry, vol. 101, no. 5, pp. 774-782, 2007.

[31] R. F. V. de Souza and W. F. de Giovani, "Synthesis, spectral and electrochemical properties of $\mathrm{Al}(\mathrm{III})$ and $\mathrm{Zn}$ (II) complexes with flavonoids," Spectrochimica Acta Part A, vol. 61, no. 19, pp. 1985-1990, 2005.

[32] S. Yaman, P. de Hoog, G. Amadei, and J. Reedijk, "Platinated copper(3-clip-phen) complexes as effective DNA-cleaving and cytotoxic agents," Chemistry, vol. 14, no. 11, pp. 3418-3426, 2008.

[33] Z.-F. Chen, Y.-C. Liu, L.-M. Liu, et al., "Potential new inorganic antitumour agents from combining the anticancer traditional Chinese medicine (TCM) liriodenine with metal ions, and DNA binding studies," Dalton Transactions, no. 2, pp. 262-272, 2009.

[34] D. R. Philip and V. R. Mikhail, "Thermodynamics of hydrogen bond and hydrophobic interactions in cyclodextrin cmplexes," Biophysical Journal, vol. 71, no. 4, pp. 2144-2154, 1996.

[35] G. Gattuso, D. Barreca, C. Gargiulli, U. Leuzzi, and C. Caristi, "Flavonoid composition of citrus juices," Molecules, vol. 12, no. 8, pp. 1641-1673, 2007.

[36] A. C. John and H. G. Petering, "The antitumor activity of $\mathrm{Cu}(\mathrm{II}) \mathrm{KTS}$, the copper (II) chelate of 3-ethoxy-2oxobutyraldehyde bis(thiosemicarbazone)," Cancer Research, vol. 27, no. 7, pp. 1278-1285, 1967.

[37] I. P. Gabriel, C. G. Anna, A. C. Hotze, C. Sanchez-Cano, B. M. Kariuki, and M. J. Hannon, "Dinuclear ruthenium(II) triplestranded helicates: luminescent supramolecular cylinders that bind and coil DNA and exhibit activity against cancer cell lines," Angewandte Chemie International Edition, vol. 46, no. 23, pp. 4374-4378, 2007.

[38] M. A. Galindo, D. Olea, M. A. Romero, et al., "Design and non-covalent DNA binding of platinum (II) metallacalix arenes," Chemistry, vol. 13, no. 18, pp. 5075-5081, 2007.

[39] R. Tamilarasan and D. R. McMillin, "Photophysical studies of copper phenanthrolines bound to DNA," Inorganic Chemistry, vol. 29, no. 15, pp. 2798-2802, 1990.

[40] A. Mazumder and D. M. Perrin, "Chemical nucleases," Chemical Reviews, vol. 93, no. 6, pp. 2295-2316, 1993. 
[41] K. A. Meadows, F. Liu, J. Sou, B. P. Hudson, and D. R. McMillin, "Spectroscopic and photophysical studies of the binding interactions between copper phenanthroline complexes and RNA," Inorganic Chemistry, vol. 32, no. 13, pp. 2919-2923, 1993.

[42] H. Ihmel, B. Engels, K. Faulhaber, and C. Lennartz, "New dyes based on amino-substituted acridizinium salts-synthesis and exceptional photochemical properties," Chemistry, vol. 6, no. 15, pp. 2854-2864, 2000.

[43] C. M. Che, M. S. Yang, K. H. Wong, H. L. Chan, and W. Lam, "Platinum(II) complexes of dipyridophenazine as metallointercalators for DNA and potent cytotoxic agents against carcinoma cell lines," Chemistry: A European Journal, vol. 5, no. 11, pp. 3350-3356, 1999.

[44] S. Mahadevan and M. Palaniandavar, "Spectroscopic and voltammetric studies on copper complexes of 2,9-dimethyl1,10-phenanthrolines bound to calf thymus DNA," Inorganic Chemistry, vol. 37, no. 4, pp. 693-700, 1998.

[45] S. Schäfer, I. Ott, R. Gust, and W. S. Sheldrick, "Influence of the polypyridyl (pp) ligand size on the DNA binding properties, cytotoxicity and cellular uptake of organoruthenium(II) complexes of the type $\left[\left(\eta^{6}-\mathrm{C}_{6} \mathrm{Me}_{6}\right) \mathrm{Ru}(\mathrm{L})(\mathrm{pp})\right]^{n+}[\mathrm{L}=$ $\left.\mathrm{CI}, n=1 ; \mathrm{L}=\left(\mathrm{NH}_{2}\right)_{2} \mathrm{CS}, n=2\right]$," European Journal of Inorganic Chemistry, vol. 2007, no. 19, pp. 3034-3046, 2007.

[46] H. Xu, K. C. Zheng, Y. Chen, et al., "Effects of ligand planarity on the interaction of polypyridyl $\mathrm{Ru}(\mathrm{II})$ complexes with DNA," Dalton Transactions, no. 11, pp. 2260-2268, 2003. 


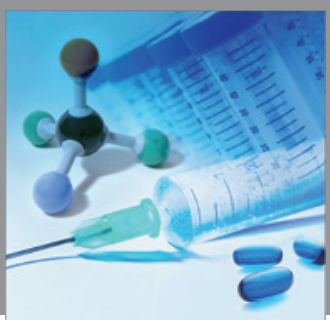

International Journal of

Medicinal Chemistry

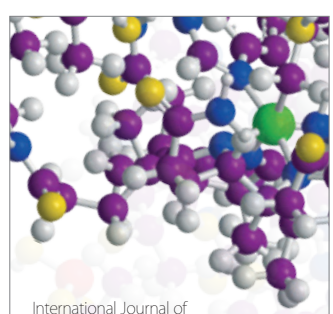

Carbohydrate Chemistry

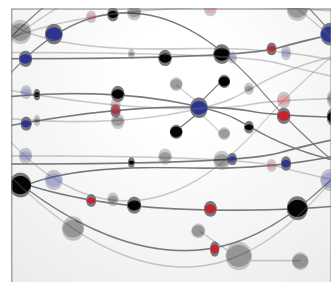

The Scientific World Journal
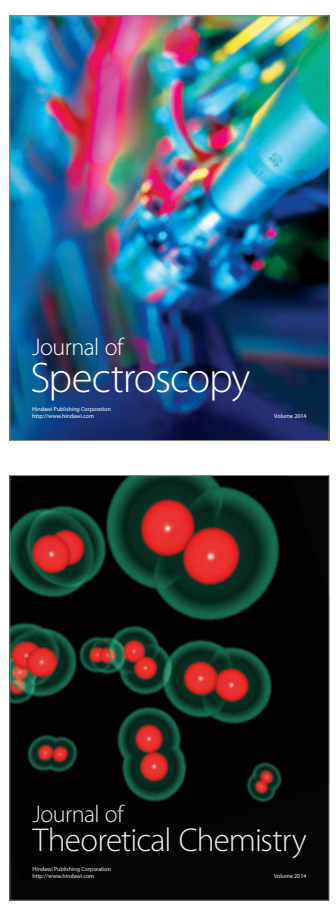
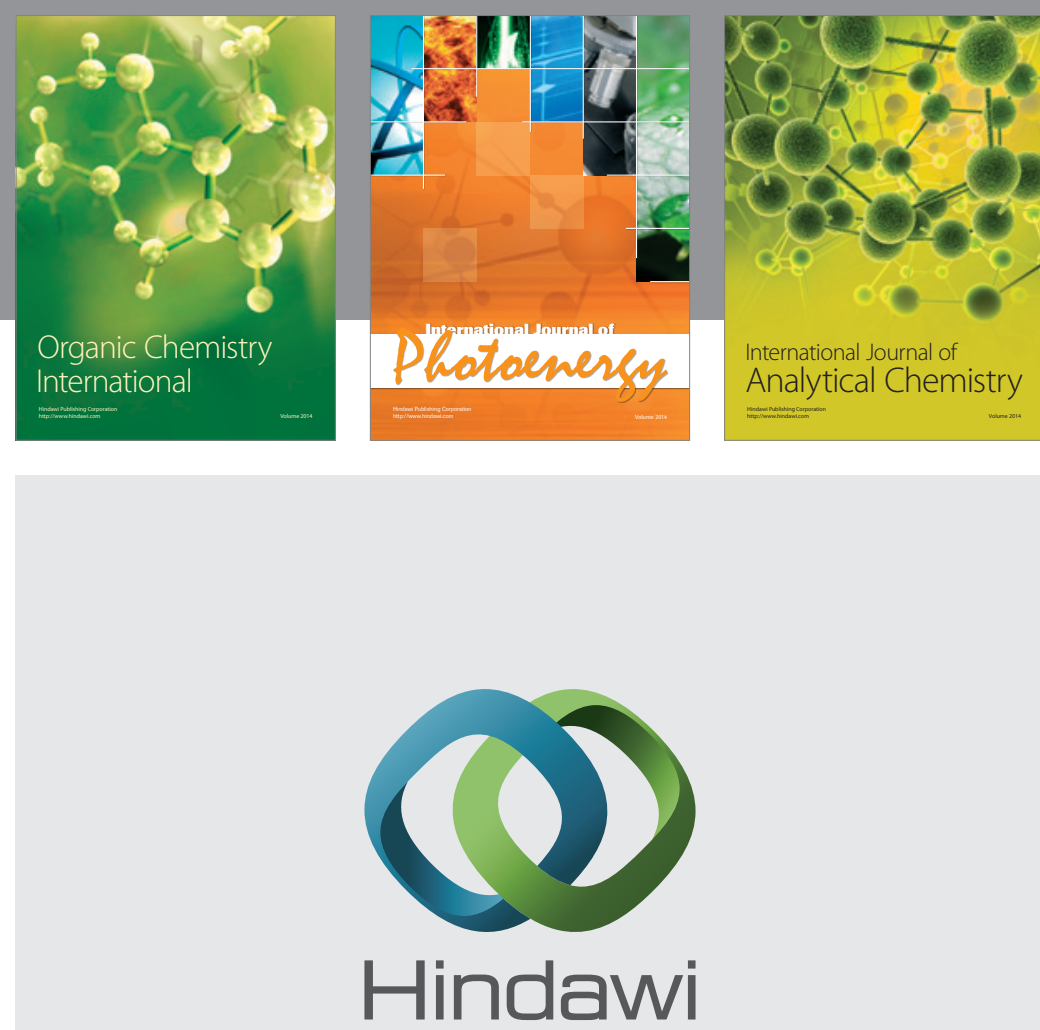

Submit your manuscripts at

http://www.hindawi.com
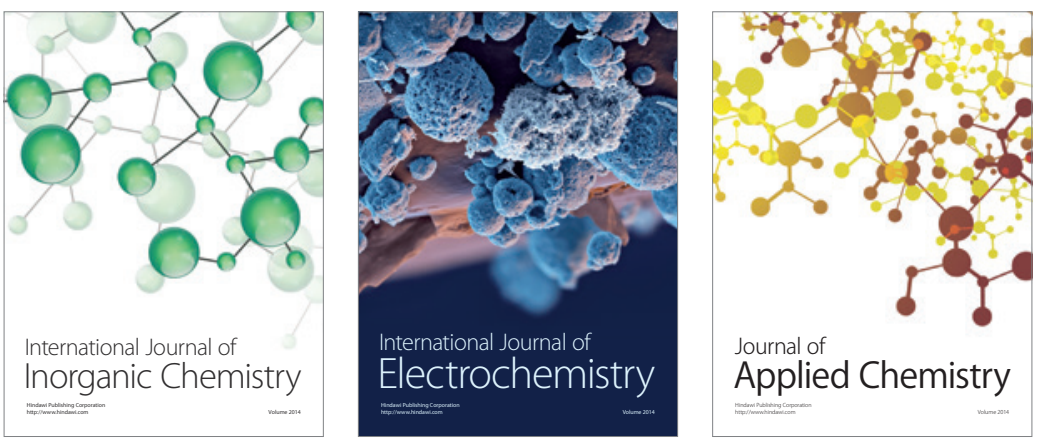

Journal of

Applied Chemistry
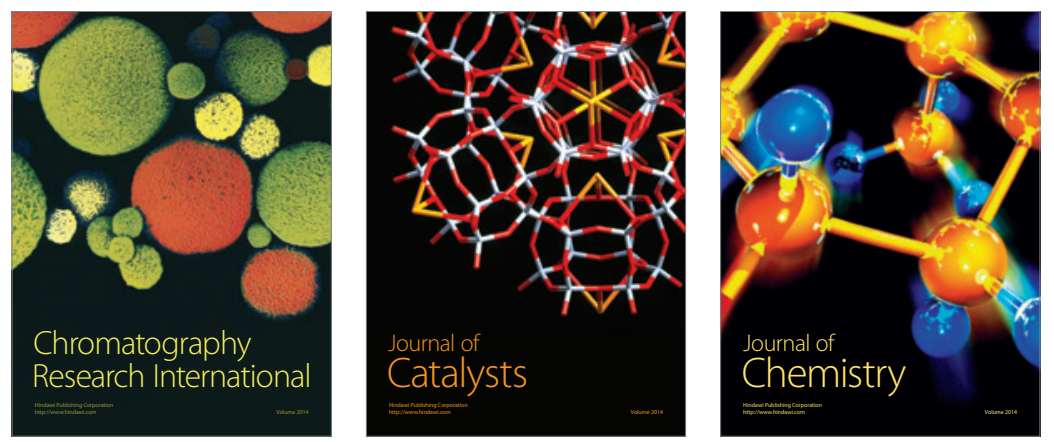
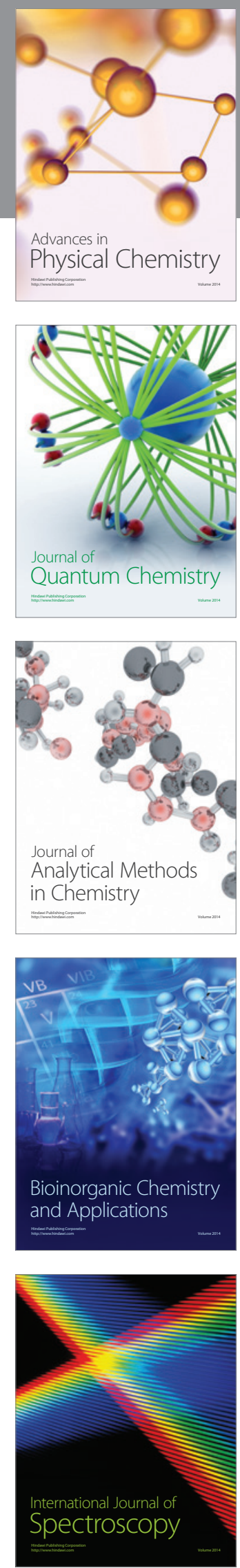